\title{
Traffic management of Udayana University Sudirman campus intersection using Vissim software
}

\author{
Putu Alit Suthanaya ${ }^{1, *}$ and Ngurah Upadiana $^{1}$ \\ ${ }^{1}$ Department of Civil Engineering, Universitas Udayana, Denpasar, Indonesia
}

\begin{abstract}
The city of Denpasar is the capital of Bali Province, as well as the centre of various activities including government offices, hospitals, schools/ universities, trade and services, as well as tourism. Traffic congestion in the city of Denpasar is increasing from year to year, especially at the point of the intersection node, such as at the signalised intersection of Udayana University Sudirman Campus. The high trip attraction to Udayana University Campus has exacerbated the congestion of the intersection. The purpose of this study was to examine an alternative to managing the traffic flow using the Vissim software. The required data included the intersection geometric data, traffic volume and signal timing. The calculation of the intersection's performance was conducted based on the Indonesian Highway Capacity Manual (IHCM). The simulation of the traffic flow management was conducted with the help of the Vissim software. The results of the performance analysis of the intersection conduced using Vissim Software indicated that the application of Vissim software was valid. The traffic management proposed has reduced both queue length and delay time.
\end{abstract}

\section{Introduction}

Road traffic condition in urban areas has continued to be a major concern in cities around the world. The implementation of the traffic management measures requires the use of traffic simulation software. Various traffic simulation software is available. Some of them employ wireless sensors that can be integrated with Intelligent Transport Systems (ITS). The others were also integrated with Geographic Information Systems (GIS). Traffic simulation is the application of computer software to model the traffic flow in the road network. Simulation of the traffic systems is an important tool for evaluating various traffic management alternatives that can be implemented.

Many studies have applied traffic simulation software to solve road traffic problems in different cities. The Vissim software was employed to simulate the road network in Beijing, China [1]. Several traffic management scenarios were developed and evaluated in terms of travel time, speed, queue length, and delay. They found that one-way street management in the CBD area was the best solution. Another study [2] used the Vissim software to calibrate

* Corresponding author: suthanaya@rocketmail.com 
various traffic conditions in Chennai, India. The data collected included traffic volume, traffic composition, speed, and signal timing. They calibrated the model using the Visual $\mathrm{C}++$ interface of Vissim. The parameters calibrated included driving behavior, desired speed, and acceleration. Sensitivity analysis was conducted based on the analysis of variance (ANOVA). Delay and queue length were analyzed for alternative intersection design super street using Vissim software [3]. They applied 36 traffic flow scenarios for each design. They claimed that compared to conventional design, the super street intersection design decreased the delay time and queue length. They found that the delay reduction was between $27.39 \%$ and $82.26 \%$ while the reduction in queue length was about $97.5 \%$. Saturation flow and the delay model were developed for junctions in Bangalore, India using the Vissim software [4]. They stated that the results of traffic simulation by Vissim were valid and that the improvement proposal could reduce the intersection delay. Vissim software was also applied to simulate traffic at three intersections in Ravet Stretch, Pune, India [5]. They found that by adding signals at the roundabout and using optimized signal timings, they could reduce the travel time. Another study [6] applied Vissim software to optimize the traffic signal timings to reduce queue length and delay at a signalized intersection in Cukurova University. They suggested that increasing the green period was the best solution to reduce the loss of time and vehicle emissions.

Several studies have focused on the calibration process and comparisons of the available traffic simulation software. An efficient methodology was developed to improve the calibration procedure of the Vissim model [7]. They applied the particle swarm optimization (PSO) method for an auto-calibration approach. They stated that the carfollowing and lane changing models were the two fundamental components of the traffic micro-simulation. A similar study [8] developed a methodology for the calibration of vehicle class-wise driving behavior in a heterogeneous traffic environment in Kolkata, India. They modeled the study area using the Vissim software. They used both single and multi-criteria calibration approaches based on a generic algorithm. The vehicle travel time was taken as the performance measure. A comparison of eleven software traffic simulators, namely Aimsum, Archisim, Corsim, Matsim, Mitsimlab, Paramics, Simtraffic, Sumo, Transims, Transmodeler, and Vissim was conducted [9]. They found that in terms of the coding flexibility in the various infrastructure elements, Aimsun, Paramics, and Vissim were found to be more flexible than the other simulators.

Different from developed countries, road traffic in developing countries like Indonesia consists of different categories of vehicles and road traffic characteristics. The traffic flow is dominated by motorcycles, with a composition of about $80 \%$. Therefore, the application of traffic simulation software, such as Vissim, need to consider this condition during the calibration process. The Vissim software is widely used in traffic management studies. This study used the Vissim software to analyze signalized traffic at Udayana University Sudirman Campus intersection in Denpasar City, Bali, Indonesia. Denpasar city is the capital of Bali province, which is experiencing a considerable population increase, mainly because of urbanization. This increase in population has been followed by an increase in the number of motor vehicles. Growing traffic in Denpasar city has led to an increase in the traffic congestion problem. The queue and delay time at almost all signalized intersections in the central city has become longer. The simulation is very useful and can reflect the dynamic flow of road traffic.

Udayana University Sudirman Campus's signalized intersection experiences long queues and delay times because of the vehicles generated by the university. Several traffic management strategies need to be analyzed to solve the problem. This study used the Vissim software to simplify the process of analyzing the performance of the intersection signal and alternative settings for the intersection that can be applied. Vissim is a simulation software used for microscopic multi-modal traffic, public transport and pedestrians, 
developed by PTV Planung Transport Verkehr AG in Karlsruhe, Germany. Vissim is the most advanced tool available to simulate multi-modal traffic flows, including that of cars, freight, buses, motorcycles, bicycles, and pedestrians. The objectives of this study are to calibrate the Vissim software based on the traffic data collected and to analyze alternative traffic management strategies.

\section{Road traffic simulation model}

According to [9], traffic simulation models can be divided into three classes. The first class is microscopic models, which are used to simulate the characteristics of individual vehicles. They simulate vehicle movements within a road network. The facilities provided include acceleration, deceleration, lane changes, and overtaking. The second class is mesoscopic models. The traffic is represented by small groups of traffic entities with a medium level of interaction detail. The third class is the macroscopic models. They simulate the flow of traffic in a road network. The traffic characteristics considered include speed, flow, and density. These models can be used to predict the spatial and temporal congestion of a road network.

VISSIM is claimed to be one of the traffic simulators that offer easy coding when it comes to constructing the road network [9]. PTV VISSIM was developed by PTV (Planung Transport Verkehr AG) in Karlsruhe, Germany [10]. VISSIM is an item of traffic simulation software widely used to evaluate traffic management alternatives for implementation consideration. In the VISSIM software, the user is allowed to define the vehicle types including motorcycles, cars, buses, trucks, heavy vehicles, light rail, pedestrians, and cyclists. The component object model (COM) programming interface is an important feature of VISSIM. This interface enables the users to develop and implement their applications in the VISSIM network using computer programming language such as $\mathrm{C}++$.

VISSIM can be used for multi-modal simulations. The types of traffic that can be simulated include cars, buses, trucks, trams, buses, bicycles, motorcycles, pedestrians, and rickshaws. Users of this software can model any geometry configuration or user path behavior that occurs in the transport system. Vissim is used to meet many traffic and public traffic simulation needs, such as traffic deceleration schemes, the study of Light Rail/ Bus Rapid Transit, the approximate use of a corresponding Intelligent Transport System, complex signal intangibles and so on. Vissim has been used to analyze networks of all sizes, including individual junction distances in an entire metropolitan area. In transport networks, Vissim can model all road classification functions ranging from highways to motorcycles and from highways for cars. The wide range of Vissim network applications includes public transport facilities, bicycles, and pedestrians. In addition, Vissim can also simulate the geometry and unique operational conditions contained in the transportation system.

\section{Methodology}

Denpasar city is the most populous city in Bali, with the population as according to the data of the Bureau of Statistics [11]. Denpasar city has 897,300 inhabitants with an area of $12,778 \mathrm{~km}^{2}$. Economic development due to tourism affects competitiveness, especially in the field of transportation. This is seen with an increase in private vehicle ownership in the city of Denpasar, which has increased from year to year. By 2016, the number of motor vehicles in Denpasar reached 1,255,635. According to the type of vehicles documented, there were 170,633 passenger cars, 44,478 freight cars, 2,180 buses, and 1,038,344 
motorcycles [11]. This also increased traffic volume, which has caused traffic problems such as the intersections.

The steps in this study started with a preliminary study, problem identification, and goal setting. The purpose of the preliminary study was to determine the data parameters to be used in the data processing and also to determine the methods needed to collect the data. Udayana University Sudirman Campus's signalized intersection is a four-legged intersection. The primary data collected included the traffic volume of each leg of the intersection approaches. The signalized intersection performances measured included queue length and delay time, which was calculated based on the Indonesian Highway Capacity Manual [12]. The traffic management simulation was performed using the Vissim software.

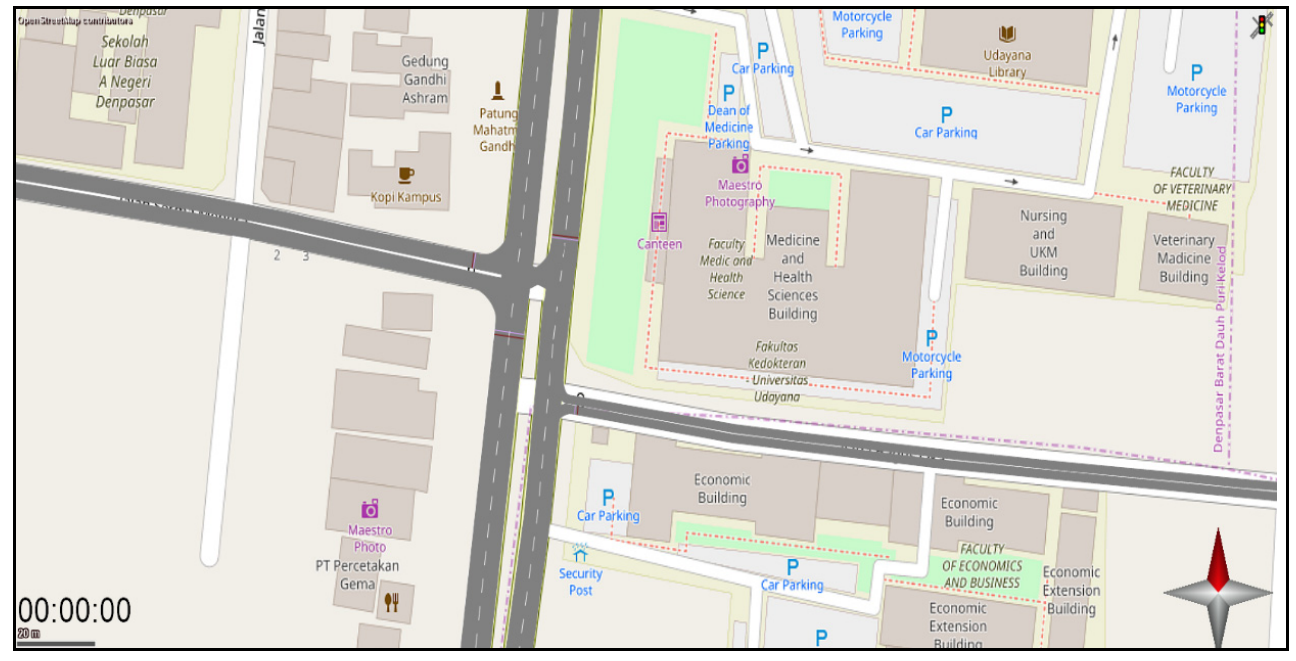

Fig. 1. Udayana University Sudirman campus intersection in Vissim software .

Table 1. Intersection geometrics

\begin{tabular}{|l|c|c|c|c|c|c|c|}
\hline $\begin{array}{c}\text { Legs of the } \\
\text { intersection }\end{array}$ & Code & $\begin{array}{c}\text { Lane } \\
\text { width } \\
\mathbf{W}_{\mathbf{A}}(\mathbf{m})\end{array}$ & $\begin{array}{c}\text { No of } \\
\text { lane }\end{array}$ & $\begin{array}{c}\text { Entance } \\
\text { width } \\
\mathbf{W}_{\text {entrance }}(\mathbf{m})\end{array}$ & $\begin{array}{c}\text { Exit } \\
\text { width } \\
\mathbf{W}_{\text {exit }}(\mathbf{m})\end{array}$ & $\begin{array}{c}\text { Pedestria } \\
\text { n facility } \\
\text { width (m) }\end{array}$ & $\begin{array}{c}\text { Median } \\
\text { (m) }\end{array}$ \\
\hline P.B. Sudirman & $\mathrm{NR}$ & 6.75 & 2 & 3.65 & 3.40 & 1.30 & 2.85 \\
\hline P.B. Sudirman & $\mathrm{NL} / \mathrm{NS}$ & 6.75 & 2 & 3.65 & 6.90 & 1.30 & 2.85 \\
\hline P.B. Sudirman & $\mathrm{S}$ & 7.50 & 2 & 7.50 & 7.65 & 1.30 & 2.85 \\
\hline Ida Bagus Oka & $\mathrm{E}$ & 3.60 & 1 & 2.28 & 6.90 & - & - \\
\hline Serma Mendra & $\mathrm{W}$ & 6.60 & 2 & 3.70 & 6.90 & 1.30 & - \\
\hline
\end{tabular}

Figure 1 shows the map of the Udayana University Sudirman Campus intersections. Table 1 and Fig. 2 show the Udayana University Sudirman Campus signalized intersection geometrics. The first step in the analysis of the software was to add links. Links (road networks) were modeled on the Vissim software to describe the shape of the geometric paths in the field. The links were made by adjusting each leg of the intersection. After the creation of the links, the next step was the input of the vehicles. The vehicle type, customized, predefined and self-defined categories were determined. In this menu, there 
were several parameters entered such as vehicle category, vehicle model, color, acceleration, deceleration, capacity, occupancy, and others.

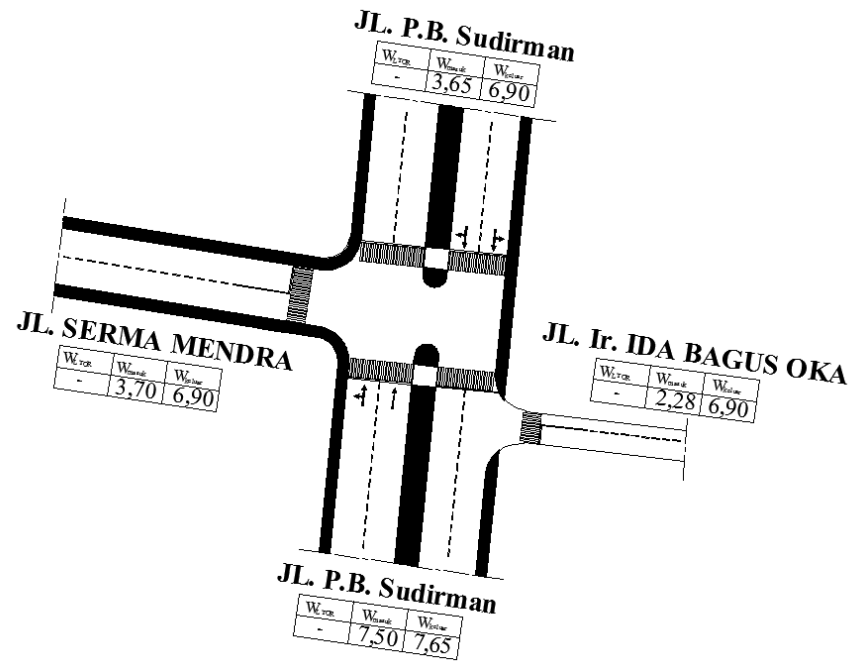

Fig. 2. Intersection geometric.

The next steps were to define the vehicle classes and to classify the vehicle types into the different categories of vehicle. In this study, the vehicle classes were divided into four classes of vehicles, available on Vissim; motorcycle, car, HGV, and bus. The traffic volumes were entered based on the survey data.

The next step was fixing the signal timing according to the traffic flow. A signal group was made at each intersection. After creating the signal groups, the next step was to create the signal programs for various signal groups. The cycle time for each signal group was determined. The suitability of the signal set was then checked.

\section{Results and discussion}

\subsection{Existing intersection performance}

The intersection performance measured included queue length, the vehicles stopping, and delay time. Table 2 shows the intersection performance in the morning, noon, and afternoon peak periods. The capacity in the morning peak hour was $794 \mathrm{pcu} /$ hour with a saturation value of 0.51 for the North approach. In the Western approach, the capacity was 468 $\mathrm{pcu} /$ hour with a saturation value of 1.31 . The intersection service level in the morning, noon and afternoon were at the $\mathrm{F}$ level, which indicates that the average delay at peak hours exceeded $60 \mathrm{sec} / \mathrm{pcu}$.

\subsection{Model validation}

The traffic volume simulated with the Vissim software was validated based on the peak hour traffic volume data. Fig. 3 shows the signal set in the Vissum software.

The traffic signal was set based on 3 phases with an early cut off system. Validation was conducted to find out whether the number of vehicles input into the software was following the situation in the field. A comparison between what was predicted and what was observed was calculated based on the t-test method. Based on the t-test, it was found that the value of 
Table 2. Performance of the intersections.

\begin{tabular}{|c|c|c|c|c|c|c|}
\hline \multirow{2}{*}{ Legs } & \multicolumn{6}{|c|}{ Morning peak hour } \\
\hline & $\begin{array}{c}\text { C } \\
\text { (pcu/hour) }\end{array}$ & DS & $\begin{array}{l}\text { QL } \\
\text { (m) }\end{array}$ & $\begin{array}{c}\text { NS } \\
\text { (stop.pcu) }\end{array}$ & $\begin{array}{c}\text { D } \\
(\mathrm{sec} / \mathrm{pcu})\end{array}$ & LOS \\
\hline P.B. Sudirman (NR) & 794 & 0.51 & 20 & 0.733 & & \\
\hline P.B. Sudirman (NL/NS) & 1228 & 1.37 & 219.178 & 5.979 & & \\
\hline Serma Mendra (W) & 468 & 1.48 & 219.178 & 6.087 & 506.886 & $\mathrm{~F}$ \\
\hline P.B. Sudirman (S) & 1228 & 0.47 & 54.321 & 0.832 & & \\
\hline Ida Bagus Oka (E) & 272 & 0.66 & 27.027 & 0.899 & & \\
\hline P.B. Sudirman (NR) & 801 & 0.54 & 20 & 0.743 & & \\
\hline P.B. Sudirman (NL/NS) & 1117 & 1.41 & 219.178 & 6.048 & & \\
\hline Serma Mendra (W) & 600 & 1.03 & 147.945 & 1.537 & 424.355 & $\mathrm{~F}$ \\
\hline P.B. Sudirman (S) & 988 & 0.76 & 49.383 & 0.872 & & \\
\hline Ida Bagus Oka (E) & 349 & 0.56 & 27.027 & 0.784 & & \\
\hline P.B. Sudirman (NR) & 794 & 0.5 & 85 & 0.728 & & \\
\hline P.B. Sudirman (NL/NS) & 1228 & 1.28 & 219.178 & 4.659 & & \\
\hline Serma Mendra (W) & 468 & 1.26 & 219.178 & 4.025 & 345.558 & $\mathrm{~F}$ \\
\hline P.B. Sudirman (S) & 1228 & 0.73 & 51.825 & 0.827 & & \\
\hline Ida Bagus Oka (E) & 272 & 0.93 & 54.054 & 1.534 & & \\
\hline
\end{tabular}

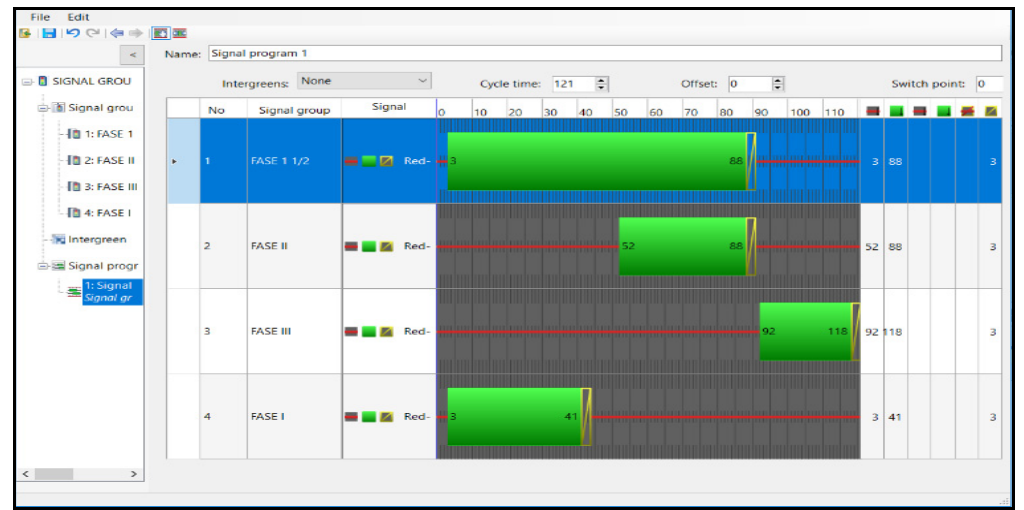

Fig. 3. Signal and phase setting in the Vissim software.

the $t$ calculation was -0.1089 . The value of the $t$ table was 1.99 based on an error rate of $5 \%$ and $\mathrm{df}=70-2=68$. Thus, the value of the $\mathrm{t}$ count was smaller than the $\mathrm{t}$ table $(-0.1089<$ 
1.99), so that Ho was accepted and Ha was rejected. It can be concluded that the traffic volume at peak hours as a result of the Vissim software was valid. Table 3 shows the validation process based on the t-test method.

Table 3. Validation process based on t-test

\begin{tabular}{|c|c|c|c|c|}
\hline Time & Legs & Manouver & $\begin{array}{c}\text { Traffic volume } \\
\text { observed } \\
\text { (pcu/hour) }\end{array}$ & $\begin{array}{c}\text { Traffic volume } \\
\text { simulated with } \\
\text { Vissim (pcu/hour) }\end{array}$ \\
\hline \multirow{12}{*}{$\begin{array}{c}\text { Morning } \\
\text { Peak }\end{array}$} & \multirow{3}{*}{$\begin{array}{l}\text { North, P.B } \\
\text { Sudirman }\end{array}$} & Left turn & 89 & 147 \\
\hline & & Straight & 1581 & 1602 \\
\hline & & Right turn & 409 & 287 \\
\hline & \multirow{3}{*}{$\begin{array}{l}\text { South, P.B } \\
\text { Sudirman }\end{array}$} & Left turn & 255 & 314 \\
\hline & & Straight & 703 & 665 \\
\hline & & Right turn & - & - \\
\hline & \multirow{3}{*}{ East, Ida Bagus Oka } & Left turn & 150 & 153 \\
\hline & & Straight & - & - \\
\hline & & Right turn & - & - \\
\hline & \multirow{3}{*}{$\begin{array}{l}\text { West, Serma } \\
\text { Mendra }\end{array}$} & Left turn & 326 & 244 \\
\hline & & Straight & 54 & 43 \\
\hline & & Right turn & 235 & 210 \\
\hline \multirow{12}{*}{$\begin{array}{l}\text { Noon } \\
\text { Peak }\end{array}$} & \multirow{3}{*}{$\begin{array}{l}\text { North, P.B } \\
\text { Sudirman }\end{array}$} & Left turn & 103 & 140 \\
\hline & & Straight & 1462 & 1532 \\
\hline & & Right turn & 403 & 272 \\
\hline & \multirow{3}{*}{$\begin{array}{l}\text { South, P.B } \\
\text { Sudirman }\end{array}$} & Left turn & 232 & 249 \\
\hline & & Straight & 560 & 541 \\
\hline & & Right turn & - & - \\
\hline & \multirow{3}{*}{ East, Ida Bagus Oka } & Left turn & 163 & 162 \\
\hline & & Straight & - & - \\
\hline & & Right turn & - & - \\
\hline & \multirow{3}{*}{$\begin{array}{l}\text { West, Serma } \\
\text { Mendra }\end{array}$} & Left turn & 272 & 286 \\
\hline & & Straight & 55 & 56 \\
\hline & & Right turn & 298 & 244 \\
\hline
\end{tabular}




\begin{tabular}{|c|c|c|c|c|}
\hline Time & Legs & Manouver & $\begin{array}{l}\text { Traffic volume } \\
\text { observed } \\
\text { (pcu/hour) }\end{array}$ & $\begin{array}{c}\text { Traffic volume } \\
\text { simulated with } \\
\text { Vissim (pcu/hour) }\end{array}$ \\
\hline \multirow{12}{*}{$\begin{array}{l}\text { Afternoon } \\
\text { Peak }\end{array}$} & \multirow{3}{*}{$\begin{array}{l}\text { North, P.B } \\
\text { Sudirman }\end{array}$} & Left turn & 80 & 141 \\
\hline & & Straight & 1489 & 1539 \\
\hline & & Right turn & 399 & 273 \\
\hline & \multirow{3}{*}{$\begin{array}{l}\text { South, P.B } \\
\text { Sudirman }\end{array}$} & Left turn & 259 & 309 \\
\hline & & Straight & 684 & 655 \\
\hline & & Right turn & - & - \\
\hline & \multirow{3}{*}{ East, Ida Bagus Oka } & Left turn & 212 & 194 \\
\hline & & Straight & - & - \\
\hline & & Right turn & - & - \\
\hline & \multirow{3}{*}{$\begin{array}{l}\text { West, Serma } \\
\text { Mendra }\end{array}$} & Left turn & 299 & 241 \\
\hline & & Straight & 50 & 42 \\
\hline & & Right turn & 214 & 206 \\
\hline \multicolumn{3}{|c|}{ Average } & 408.7407407 & 398.037037 \\
\hline \multicolumn{3}{|c|}{ SD } & 433.2621868 & 445.3066775 \\
\hline \multicolumn{3}{|c|}{ Variance } & 187716.1225 & 198298.037 \\
\hline \multicolumn{3}{|c|}{$\mathrm{R}$} & \multicolumn{2}{|c|}{0.99195863} \\
\hline
\end{tabular}

\subsection{Intersection performances based on Vissim simulation}

The traffic management was evaluated based on the simulation of traffic flow where the entrance of Udayana University Campus was re-located to the north, and the exit was moved to a minor road of Ida Bagus Oka Street. For the morning peak period, it was found that the maximum queue length that occurred in the northern leg of the intersection was $177.7 \mathrm{~m}$, the vehicles that came during the red signal was $1,932 \mathrm{pcu} /$ hour, and the average vehicle delay was $74.1 \mathrm{sec} / \mathrm{pcu}$ with service level F. The simulation results can be seen in Fig. 5. Table 4 shows the results of the comparison between the existing intersection performance and the performance after the traffic management was simulated using the Vissim software.

The results of the simulation for the noon peak hour as indicated by the value of the maximum queue length for the north approach was $89.65 \mathrm{~m}$. The number of vehicles that came during the red light was $1180 \mathrm{pcu} /$ hour, and the average vehicle delay was 73.3 $\mathrm{sec} / \mathrm{pcu}$ with the level of service being the F level. For the afternoon peak period, the value of the maximum queue length that occurred in the northern approach was $35.4 \mathrm{~m}$, the vehicles that came during the red light was $455 \mathrm{pcu} /$ hour, and the average vehicle delay was $105.7 \mathrm{sec} / \mathrm{pcu}$ with an F level of service. 


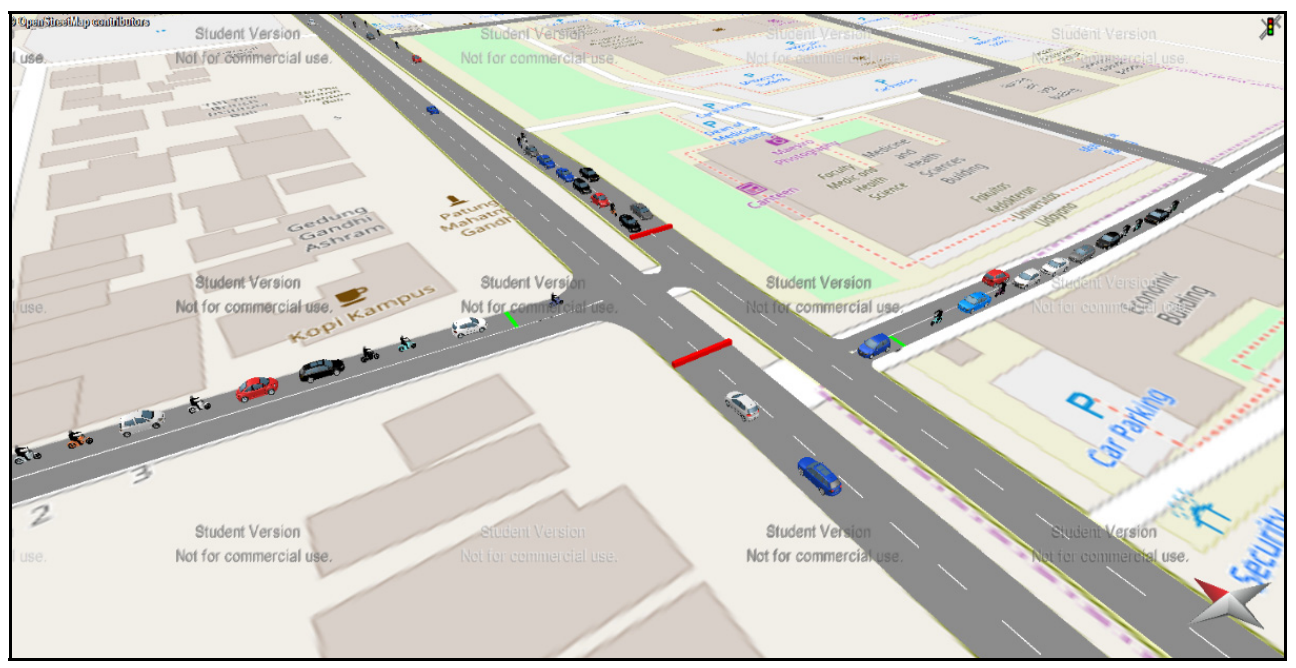

Fig. 5. Result of the Vissim traffic simulation for the morning peak period.

Table 4. Comparison between before and after traffic management.

\begin{tabular}{|c|c|c|c|c|c|c|}
\hline \multirow{2}{*}{ Movement } & \multicolumn{3}{|c|}{ Queue Length (m) } & \multicolumn{3}{|c|}{ Average Vehicle Delay (sec/pcu) } \\
\hline & Before & After & $\%$ & Before & After & $\%$ \\
\hline South-ST & 139.067 & 139.067 & 0 & \multirow{9}{*}{74.0488} & \multirow{9}{*}{74.003} & \multirow{9}{*}{-0.0619} \\
\hline South-LT & 139.067 & 139.067 & 0 & & & \\
\hline North-ST & 276.442 & 177.745 & -35.7 & & & \\
\hline North-RT & 276.442 & 177.745 & -35.7 & & & \\
\hline North-LT & 276.442 & 177.745 & -35.7 & & & \\
\hline W-RT & 171.7 & 171.692 & -0.005 & & & \\
\hline W-LT & 171.7 & 171.692 & -0.005 & & & \\
\hline W-ST & 171.7 & 171.692 & -0.005 & & & \\
\hline E-LT & 35.908 & 66.492 & 85.173 & & & \\
\hline Average & 184.274 & 154.771 & -2.439 & & & \\
\hline
\end{tabular}

\section{Conclusions}

The results of the performance analysis of the intersection using the Vissim Software indicated that the application of the Vissim software was valid. Based on the t-test, it was determined that the value of the $t$ calculation was -0.1089 , while the $t$ table was 1.99 . Thus, 
the value of the $t$ count was smaller than the $t$ table $(-0.1089<1.99)$. By comparing the before and after the performance of the intersection based on the Vissim simulation, it was found that the queue length decreased by $-35.7 \%$ from $276.4 \mathrm{~m}$ to $177.7 \mathrm{~m}$ and that the delay decreased by $0.06 \%$ from $74.088 \mathrm{sec} / \mathrm{pcu}$ to $74.003 \mathrm{sec} / \mathrm{pcu}$.

\section{References}

1. D. Lin, X. Yang, C. Gao. Proc. Social and Behavioral Science 96 (2013)

2. H.H. Naghawi, W.I. Idewu. J. of the South African Institution of Civil Eng. 56 (2014)

3. S.M.P. Siddharth, G. Ramadurai. Proc. Social and Behavioral Science 104 (2013)

4. B. Vinayaka, R.L. Kadam. Int. J. of Eng. Res. and Tech. 5 (2016)

5. M. Shah, R.M. Kumawat, M.V. Yadav, R.P. Tidake. Int. J. for Sci. Res. Dev. 5 (2017)

6. G. Tuccar, E. Uludamar. European Mechanical Sci. 1 (2017)

7. K. Aghabayk, M. Sarvi, W. Young, L. Kautzsch. Proc. of Australasian Transport Research Forum (ATRF) 2013 (2013)

8. P. Maheshwary, K. Bhattacharyya, B. Maitra, M. Boltze. Proc. World Conference on Transport Research (WCTR) Shanghai 2016 (2016)

9. M. Saidallah, A.E. Fergougui, A.E. Elalaoui. Matec Web of Conference 81 (2016).

10. PTV VISSIM. VISSIM 5.10 COM Interface Manual (PTV AG, Karisruhe, 2009)

11. Bureau of Statistics. Denpasar in Figure 2016 (Denpasar, 2016)

12. Department of Public Work. Indonesian Highway Capacity Manual (IHCM) (Department of Public Work Republic of Indonesia, Jakarta, 1997) 